\title{
Determination of the High Temperature Stress Tolerances of Bread Wheat Genotypes
}

\author{
Zahit Kayıhan Korkut, Alpay Balkan, İsmet Başer and Oğuz Bilgin \\ Namık Kemal University, Agricultural Faculty, Field Crops Department, Tekirdağ 59030, Turkey
}

\begin{abstract}
Thirty bread wheat genotypes were used as material during the 2014-2015 cropping season. The experimental layout was a randomized complete block design with 3 replications. The sowing rate was 500 seeds square meter. Sowing was done in plots of 6 rows $(1.2 \mathrm{~m} \times 5 \mathrm{~m}$, spaced $20 \mathrm{~cm}$ apart) in Namık Kemal University, Faculty of Agriculture, Field Crops Department experimental area. Two sowing times were performed. First sowing was made in November suggested usual (standard) and second one was made in January as delayed sown in order to push growing stages of plants into periods in which heat stress is expected will be effected. Sowing times were allotted to main-plots while genotypes were allotted to sub-plots. When the bread wheat varieties and lines used in the experiment are evaluated in terms of tolerance to high temperature, it was shown that Dropia and Nota varieties and CIMMYT-HTN 2014/15-2, CIMMYT-HTN 2014/15-6, CIMMYT-HTN 2014/15-10 lines were better tolerance to high temperature. However, it was noticed that these genotypes were not included in the first groups in terms of grain yield. It is possible to utilize these genotypes as a genitor in cross-breeding programs for breeding studies for tolerance to high temperatures.
\end{abstract}

Key words: Heat tolerance, bread wheat, advanced lines, heat sensitive.

\section{Introduction}

Adaptation to environmental stresses arises in the result of interrelated events emerging at the anatomical, morphological, biochemical and molecular levels. The growth and development of the plants have a great importance for the temperature and hence the water. The high temperature in the growth environment causes the degradation of the naturalness of proteins, the loss of enzyme activity and the alteration of cell structure and function. Thus, vegetation development and growth are affected negatively in plants exposed to these conditions [1].

Determination of the effects of mechanisms which are effective for tolerance to high temperature in plants is of great importance. The increased temperature negatively affects the different phases of plant growth [2]. In addition to mechanisms that tolerate high temperatures in plants, there are important factors that limit the development of stress

Corresponding author: Alpay Balkan, Ph.D., assist professor, research field: cereal physiology and breeding. tolerance in plants. These factors are complex events involving morphological, physiological and biochemical parameters among genotypes, and some shortcomings in increasing the efficiency of selection using all agronomic parameters [3] and the lack of effective methods for screening genotypes in breeding programs [4]. Because of the genotypic differences between and within species, plants respond differently to increasing temperatures [5]. These genotypic response differences are important for plant breeding in terms of environmental stresses [6].

In the developmental process of the wheat plant, it has been reported that the decrease in yield, which is caused by the high temperature stress, is related to the number of grain and grain weight per spike reduction [7-11].

Sowing time is particularly important for wheat produced in areas that do not have irrigation. Late sown crops are exposed to high temperatures during developments of growth [12], high temperatures during the seeding and grain filling stages accelerate maturating, and cause significant reductions in grain 
size and weight [13]. At higher temperatures than optimal, grain yields have been reported to decline and quality degradation has been reported in cereals [12, 14-16]. All over the world, researchers have concentrated their efforts on the identification and development of high temperature tolerant genotypes [16-25].

In this research, it was aimed to determine the effect of high temperature stress on bread wheat in Trakya Region, selection criteria that can be used in high temperature tolerance wheat breeding studies and tolerant wheat genotypes.

\section{Materials and Methods}

The research was carried out in Namık Kemal University, Faculty of Agriculture, Field Crops Department Application and Research Area during 2014-2015 growing season. In the study, the experiments were set up at two sowing times in order to create heat stress. These are Standard and late sowing. First sowing was made in November suggested usual (standard) and second one was made in January as delayed sown in order to push growing stages of plants into periods in which heat stress is expected will be effected.

The total temperatures between heading and maturating were $915.4{ }^{\circ} \mathrm{C}$ for the standard sowing and $1,084.8{ }^{\circ} \mathrm{C}$ for late sowing. The total temperature difference of heading and maturating stages between the standard and late sown was $169.4{ }^{\circ} \mathrm{C}$.

\subsection{Material}

A total of 30 bread wheat (Triticum aestivum L.) genotypes including 15 bread wheat varieties with different phenological characteristics (early, middle early, late) (Nota, Kate A1, Basribey, Gelibolu, Esperia, Saraybosna, Syrena, Flamura 85, Krasunia, Dropia, Tina, Golia, Tekirdag, Pehlivan, Yubileynaya 100) and 15 high-temperature tolerant wheat lines $\begin{array}{lcr}\text { (CIMMYT-HTN } & \text { 2014/15-1, } & \text { CIMMYT-HTN } \\ \text { 2014/15-2, } & \text { CIMMYT-HTN } & 2014 / 15-3,\end{array}$

$\begin{array}{lcr}\text { CIMMYT-HTN } & \text { 2014/15-4, } & \text { CIMMYT-HTN } \\ \text { 2014/15-5, } & \text { CIMMYT-HTN } & 2014 / 15-6, \\ \text { CIMMYT-HTN } & \text { 2014/15-7, } & \text { CIMMYT-HTN } \\ \text { 2014/15-8, } & \text { CIMMYT-HTN } & 2014 / 15-9, \\ \text { CIMMYT-HTN } & 2014 / 15-10 \text { and } & \text { CIMMYT-HTN } \\ \text { 2013/14-4464, } & \text { CIMMYT-HTN } & 2013 / 14-4488, \\ \text { CIMMYT-HTN } & 2013 / 14-4489, & \text { CIMMYT-HTN }\end{array}$
2013/14-4490, CIMMYT-HTN 2013/14-4492) from CIMMYT (International Corn and Wheat Improvement Center-Mexico) were used as plant material. Among these genotypes, Basribey variety is defined as tolerant to high temperature.

\subsection{Methods}

The experiments were carried out as split plot design based on randomized complete block design with three replications and sown on 09 November 2014 and 09 January 2015. Sowing times were allotted to main-plots while genotypes were allotted to sub-plots. The sowing rate was 500 seeds per square meter. Sowing was done by hand in plots of 6 rows $(1.2 \mathrm{~m} \times 5 \mathrm{~m}$, spaced $20 \mathrm{~cm}$ apart) in Namık Kemal University, Faculty of Agriculture, and Field Crops Department experimental area.

The $250 \mathrm{kgha}^{-1}$ of 20.20 .0 compound fertilizer (50 $\mathrm{kgha}^{-1}$ of pure nitrogen and $50 \mathrm{kgha}^{-1}$ pure phosphorus) at sowing time, Urea fertilizer $(46 \% \mathrm{~N})$ at tillering stage and ammonium nitrate fertilizer (33\%) at stem elongation stage were applied in experimental area. Moreover, based on the development status of weeds, chemical control was performed between the periods of tillering and stem elongation. The trial plots were harvested in July 2015 by HEGE 160 plot harvester.

Some characters such as number, width and length of stoma, glaucousness, heading date, thousand kernel weight, test weight and grain yield were investigated in the context of high temperature tolerance mechanisms in bread wheat varieties and lines in which the high temperature stress is effected on the plants in the late sowing condition.

The data obtained from the study were analyzed by 
variance analysis according to the method recommended by Ref. [26] using MSTAT-C computer package program. The statistical significance of differences between mean values of genotypes for the traits examined was determined by Duncan-test.

\section{Results and Discussion}

The results of variance analysis and significance test on the obtained data of the characters examined in the scope of high temperature tolerance mechanisms in the bread wheat cultivars and lines in late sowing conditions which affect high temperature stress on plants are given in Tables 1-3.

The grain yield and quality characteristics of plants are highly influenced by the abiotic and biotic stress factors that occur in the environment where they grow. Many researchers in the world have focused on the identification and development of high temperature tolerant genotypes [20-22, 25, 27].

Tolerance to abiotic stress factors such as drought, temperature, salinity are closely related to stoma movement in plants. Stomata characters such as number of stomata and their width and length in the unit area of plant leaves affect the photosynthesis capacity of plants significantly, and cause in significant changes in grain yield. Plants can be protected to a certain degree from high temperature stress with the waxy layer they form on the plant surface. Stomata are important portals for gas and water exchange in plants and have a strong influence on characteristics associated with photosynthesis and transpiration. As stomata control temperature and water use efficiency, they are vital to the existence of the plant. Stomata vary in size and density among different species and among cultivated varieties within species [28].

In this study, the stoma characteristics and glaucousness average values and significance groups determined in the bread wheat varieties and lines exposed to high temperature stress by late sowing are given in Table 1. The number of stomata, stomata length and width of wheat genotypes examined ranged from 4.667-10.667, 1.967-3.067 $\mathrm{m} \mu$ (millimicron) and $0.667-1.30 \mu \mathrm{m}$, respectively. And glaucousness values of them ranged from 1.0 to 9.0. Of the genotypes, the most number of stomata was obtained for Golia with 10.667, and followed by CIMMYT-HTN 2013/14-4464 and Gelibolu genotypes with 10.33. Krasunia, Flamura 85, Gelibolu, CIMMYT-HTN 2014/15-9 and CIMMYT-HTN 2014/15-10 were the other higher number of stomata genotypes with 10.00 units.

Under both drought stress and normal irrigation, and on the 10th and 20th day after anthesis, there were significant correlations between stomata density and stoma length and stomata width, but the correlations of between density and length of stomata changed with water condition or growth stage [29]. On the other hand, Nota were a genotype with the least number of stoma (4.667 units). This genotype was followed by CIMMYT-HTN 2014/15-3, CIMMYT-HTN 2014/15-2 and Dropia with 6.33 units. In addition to the number of stomata, stomata's length and width are closely affecting water losses in plants. The highest stomata length value in the genotypes of the bread wheat was measured for Nota with $3.067 \mathrm{m \mu}$ and for CIMMYT-HTN 2014/15-10 with $3.033 \mathrm{m \mu}$. The lowest values were found for CIMMYT-HTN 2013/14-4488 genotype with $1.967 \mathrm{~m} \mu$ followed by Saraybosna with $2.033 \mathrm{m \mu}$ and Flamura 85 and Golia with $2.067 \mathrm{~m} \mu$. Genotypes with the most stomata width were Sarayabosna, CIMMYT-HTN 2013/14-4488 and CIMMYT-HTN 2014/15-1 with $1.33 \mathrm{~m} \mu$. In comparison, the lowest stomata width was measured in CIMMYT-HTN 2014/15-10 and Dropia genotypes.

When the obtained data are examined, it is seen that the number of stomata, width and length of wheat genotypes changed according to each other. Note cultivar, which has at least the number of stomata, was found in the first important and statistical group in terms 
Table 1 Stomata properties and glaucousness averages and significance groups for bread wheat genotypes.

\begin{tabular}{|c|c|c|c|c|}
\hline Genotypes & $\begin{array}{l}\text { Number of stomata } \\
\text { (unit) }\end{array}$ & $\begin{array}{l}\text { Length of stomata } \\
(\mathrm{m} \mu)\end{array}$ & $\begin{array}{l}\text { Width of stomata } \\
(\mathrm{m} \mu)\end{array}$ & Glaucousness \\
\hline Golia & $10.667 \mathrm{a}$ & $2.067 \mathrm{fgh}$ & $1.000 \mathrm{abc}$ & $3.000 \mathrm{e}$ \\
\hline CIMMYT-HTN 2013/14-4464 & $10.333 \mathrm{ab}$ & $2.367 \mathrm{~b}-\mathrm{h}$ & $1.200 \mathrm{a}$ & $7.000 \mathrm{bc}$ \\
\hline Gelibolu & $10.333 \mathrm{ab}$ & $2.100 \mathrm{e}-\mathrm{h}$ & $1.233 \mathrm{a}$ & $6.333 \mathrm{c}$ \\
\hline Krasunia & $10.000 \mathrm{abc}$ & $2.400 \mathrm{~b}-\mathrm{h}$ & $1.033 \mathrm{abc}$ & $7.667 \mathrm{~b}$ \\
\hline Flamura 85 & $10.000 \mathrm{abc}$ & $2.067 \mathrm{fgh}$ & $1.200 \mathrm{a}$ & $3.000 \mathrm{e}$ \\
\hline CIMMYT-HTN 2014/15-9 & $10.000 \mathrm{abc}$ & $2.433 \mathrm{~b}-\mathrm{h}$ & $1.033 \mathrm{abc}$ & $7.000 \mathrm{bc}$ \\
\hline CIMMYT-HTN 2014/15-10 & $10.000 \mathrm{abc}$ & $3.033 \mathrm{a}$ & $0.667 \mathrm{c}$ & $5.000 \mathrm{~d}$ \\
\hline Saraybosna & $9.667 \mathrm{a}-\mathrm{d}$ & $2.033 \mathrm{gh}$ & $1.333 \mathrm{a}$ & $3.000 \mathrm{e}$ \\
\hline Tekirdağ & $9.333 \mathrm{a}-\mathrm{d}$ & $2.800 \mathrm{abc}$ & $1.300 \mathrm{a}$ & $1.000 \mathrm{f}$ \\
\hline Syrena & $9.333 \mathrm{a}-\mathrm{d}$ & $2.633 \mathrm{a}-\mathrm{e}$ & $0.900 \mathrm{abc}$ & $4.333 \mathrm{~d}$ \\
\hline CIMMYT-HTN2013/14-4488 & $9.333 \mathrm{a}-\mathrm{d}$ & $1.967 \mathrm{~h}$ & $1.333 \mathrm{a}$ & $7.667 \mathrm{~b}$ \\
\hline Tina & $9.333 \mathrm{a}-\mathrm{d}$ & $2.267 \mathrm{c}-\mathrm{h}$ & $1.233 \mathrm{a}$ & $9.000 \mathrm{a}$ \\
\hline CIMMYT-HTN 2014/15-6 & $9.333 \mathrm{a}-\mathrm{d}$ & $2.467 \mathrm{~b}-\mathrm{h}$ & $1.200 \mathrm{a}$ & $7.000 \mathrm{bc}$ \\
\hline Pehlivan & 9.000 a-e & $2.233 \mathrm{~d}-\mathrm{h}$ & $1.333 \mathrm{abc}$ & $9.000 \mathrm{a}$ \\
\hline CIMMYT-HTN 2014/15-4 & 9.000 a-e & $2.333 \mathrm{~b}-\mathrm{h}$ & $0.867 \mathrm{abc}$ & $1.000 \mathrm{f}$ \\
\hline Yubileynaya 100 & 9.000 a-e & $2.467 \mathrm{~b}-\mathrm{h}$ & $1.300 \mathrm{a}$ & $5.000 \mathrm{~d}$ \\
\hline CIMMYT-HTN 2014/15-8 & 8.667 a-e & $2.533 \mathrm{a}-\mathrm{g}$ & $1.000 \mathrm{abc}$ & $7.000 \mathrm{bc}$ \\
\hline CIMMYT-HTN 2013/14-4490 & $8.333 \mathrm{a}-\mathrm{e}$ & $2.467 \mathrm{~b}-\mathrm{h}$ & $1.167 \mathrm{ab}$ & $9.000 \mathrm{a}$ \\
\hline Kate A1 & $8.333 \mathrm{a}-\mathrm{e}$ & $2.433 \mathrm{~b}-\mathrm{h}$ & $1.100 \mathrm{abc}$ & $9.000 \mathrm{a}$ \\
\hline CIMMYT-HTN 2014/15-5 & $8.333 \mathrm{a}-\mathrm{e}$ & $2.833 \mathrm{ab}$ & $0.967 \mathrm{abc}$ & $3.000 \mathrm{e}$ \\
\hline CIMMYT-HTN 2014/15-7 & 8.333 a-e & $2.300 \mathrm{~b}-\mathrm{h}$ & $1.200 \mathrm{a}$ & $1.000 \mathrm{f}$ \\
\hline Basribey & $8.000 \mathrm{a}-\mathrm{e}$ & $2.633 \mathrm{a}-\mathrm{e}$ & $0.933 \mathrm{abc}$ & $7.000 \mathrm{bc}$ \\
\hline Esperia & $7.667 \mathrm{~b}-\mathrm{e}$ & $2.200 \mathrm{~d}-\mathrm{h}$ & $1.100 \mathrm{abc}$ & $5.000 \mathrm{~d}$ \\
\hline CIMMYT-HTN 2013/14-4492 & $7.333 \mathrm{c}-\mathrm{f}$ & 2.667 a-d & $1.200 \mathrm{a}$ & $9.000 \mathrm{a}$ \\
\hline CIMMYT-HTN 2013/14-4489 & $7.333 \mathrm{c}-\mathrm{f}$ & $2.600 \mathrm{a}-\mathrm{f}$ & $1.167 \mathrm{ab}$ & $9.000 \mathrm{a}$ \\
\hline CIMMYT-HTN 2014/15-1 & $7.333 \mathrm{c}-\mathrm{f}$ & $2.267 \mathrm{c}-\mathrm{h}$ & $1.333 \mathrm{a}$ & $9.000 \mathrm{a}$ \\
\hline Dropia & $7.00 \mathrm{def}$ & $2.800 \mathrm{abc}$ & $0.733 \mathrm{bc}$ & $7.000 \mathrm{bc}$ \\
\hline CIMMYT-HTN 2014/15-2 & $7.00 \mathrm{def}$ & $2.800 \mathrm{abc}$ & $1.000 \mathrm{abc}$ & $7.000 \mathrm{bc}$ \\
\hline CIMMYT-HTN 2014/15-3 & $6.333 \mathrm{ef}$ & $2.433 \mathrm{~b}-\mathrm{h}$ & $1.000 \mathrm{abc}$ & $1.000 \mathrm{f}$ \\
\hline Nota & $4.667 \mathrm{f}$ & $3.067 \mathrm{a}$ & $1.300 \mathrm{a}$ & $5.000 \mathrm{~d}$ \\
\hline
\end{tabular}

of stoma width and length. On the other hand, it is seen that the genotypes showing the highest number of stomata are not in the front row in terms of stoma width and height. When the results of number, width and length of stoma are evaluated together with grain yield, it is seen that wheat genotypes having lower values for stoma characteristics are less affected by stress conditions and consequently give better grain yields under high temperature stress conditions (Table 3). Ref. [30] found that differences in leaf stomata width in high temperature resistant and sensitive wheat varieties. Also anatomy was affected adversely under higher temperature in all ten genotypes leaf but with more affected in susceptible as compared to tolerance genotypes.

Plants consume more water and decrease net photosynthesis ratio by increasing respiratory losses in arid and high temperature conditions. These reductions are lower in genotypes that are less affected by reducing respiratory losses from high temperature conditions. The stoma properties of plants and the cuticle layer on the plant surface have a considerable effect on respiratory losses through transpiration. One of the important factors in protecting plants from high temperatures is the presence of the cuticle layer on the plant surface. When the wheat genotypes are 
examined, a high level of glaucous layer was determined in the genotypes of Tina, Pehlivan, Kate A1, CIMMYT-HTN 2013/14-4490, CIMMYT-HTN 2013/14-4492, CIMMYT-HTN 2013/14-4489 and CIMMYT-HTN 2014/15-1, no glaucous layer was observed in CIMMYT-HTN 2014/15-4, CIMMYT-HTN 2014/15-3, CIMMYT-HTN 2014/15-7 and Tekirdağ genotypes. On the other hand, Golia, Saraybosna, CIMMYT-HTN 2014/15-7 genotypes have a low level of glaucousness.

Results of the heading time and the thousand kernel weight obtained from standard and late sowing for wheat genotypes are given in Table 2 .

The heading time of 30 wheat genotypes varied from 164.33 to 172.33 days for standard sowing and from 119.0 to 126.33 days for late sowing. This shows that plants that have been sown late reached the period of physiological maturity in 30-40 days shorter than those sown on standard date. CIMMYT-HTN 2014/15-7 showed the longest heading time for standard sowing with 172.33 days, followed by Syrena and CIMMYT-HTN 2014/15-9 for 171.33 days. The shortest heading time was 164.33 days for Golia, followed by 164.67 days for CIMMYT-HTN2013/14-4488

Table 2 Mean values and significances of heading time and thousand kernel weight for bread wheat genotypes.

\begin{tabular}{|c|c|c|c|c|c|c|}
\hline \multirow[b]{2}{*}{ Genotypes } & \multicolumn{3}{|c|}{ Heading time (days) } & \multicolumn{3}{|c|}{ Thousand kernel weight (g) } \\
\hline & $\begin{array}{l}\text { Standard } \\
\text { sowing }\end{array}$ & $\begin{array}{l}\text { Late } \\
\text { sowing }\end{array}$ & Mean & $\begin{array}{l}\text { Standard } \\
\text { sowing }\end{array}$ & $\begin{array}{l}\text { Late } \\
\text { sowing }\end{array}$ & Mean \\
\hline Golia & 164.331 & $119.00 \mathrm{t}$ & $141.67 \mathrm{kl}$ & 26.33 rst & 24.33 g-n & $25.33 n$ \\
\hline CIMMYT-HTN 2013/14-4464 & $164.67 \mathrm{~h} 1$ & $118.00 \mathrm{tu}$ & 141.331 & $43.67 \mathrm{a}$ & 39.33 b-e & $41.50 \mathrm{a}$ \\
\hline Gelibolu & $167.67 \mathrm{ef}$ & $123.671-0$ & 145.67 efg & 34.33 g-n & $34.67 \mathrm{f}-\mathrm{m}$ & $34.50 \mathrm{gh}$ \\
\hline Krasunia & $170.33 \mathrm{bc}$ & $124.00 \mathrm{lmn}$ & $147.17 \mathrm{bcd}$ & $34.67 \mathrm{f}-\mathrm{m}$ & $36.33 \mathrm{c}-\mathrm{k}$ & $35.50 \mathrm{~d}-\mathrm{h}$ \\
\hline Flamura 85 & $170.33 \mathrm{bc}$ & $123.33 \mathrm{~m}-\mathrm{p}$ & $146.83 \mathrm{~cd}$ & $36.33 \mathrm{c}-\mathrm{k}$ & $35.67 \mathrm{c}-1$ & $36.00 \mathrm{c}-\mathrm{g}$ \\
\hline CIMMYT-HTN 2014/15-9 & $171.33 \mathrm{ab}$ & $126.33 \mathrm{k}$ & $148.83 \mathrm{a}$ & $38.00 \mathrm{c}-\mathrm{h}$ & $37.33 \mathrm{c}-\mathrm{j}$ & $37.67 \mathrm{c}-\mathrm{f}$ \\
\hline CIMMYT-HTN 2014/15-10 & $168.00 \mathrm{ef}$ & $123.00 \mathrm{~m}-\mathrm{q}$ & $145.50 \mathrm{e}-\mathrm{h}$ & 26.33 rst & $28.67 \mathrm{p}-\mathrm{t}$ & $27.50 \mathrm{mn}$ \\
\hline Saraybosna & $171.33 \mathrm{ab}$ & $124.33 \mathrm{~lm}$ & $147.33 \mathrm{abc}$ & $25.67 \mathrm{t}$ & $27.67 \mathrm{q}-\mathrm{t}$ & $26.67 n$ \\
\hline Tekirdağ & $168.67 \mathrm{de}$ & $122.33 \mathrm{o}-\mathrm{s}$ & $145.50 \mathrm{e}-\mathrm{h}$ & $38.00 \mathrm{c}-\mathrm{h}$ & $38.33 \mathrm{c}-\mathrm{h}$ & $38.17 \mathrm{~b}-\mathrm{e}$ \\
\hline Syrena & $171.33 \mathrm{ab}$ & 125.001 & $148.17 \mathrm{ab}$ & $36.33 \mathrm{c}-\mathrm{k}$ & $39.00 \mathrm{~b}-\mathrm{f}$ & $37.67 \mathrm{c}-\mathrm{f}$ \\
\hline CIMMYT-HTN2013/14-4488 & $164.67 \mathrm{~h} 1$ & $118.00 \mathrm{tu}$ & 141.331 & $38.33 \mathrm{c}-\mathrm{h}$ & $38.33 \mathrm{c}-\mathrm{h}$ & $38.33 \mathrm{a}-\mathrm{d}$ \\
\hline Tina & $170.33 \mathrm{bc}$ & $123.671-0$ & $147.00 \mathrm{~cd}$ & $35.33 \mathrm{~d}-1$ & $35.00 \mathrm{c}-\mathrm{m}$ & $35.17 \mathrm{e}-\mathrm{h}$ \\
\hline CIMMYT-HTN 2014/15-6 & $168.67 \mathrm{de}$ & $122.67 \mathrm{lmn}$ & 145.67 efg & $37.67 \mathrm{~d}-1$ & $40.00 \mathrm{abc}$ & $38.83 \mathrm{abc}$ \\
\hline Pehlivan & $168.67 \mathrm{de}$ & $124.33 \mathrm{~lm}$ & $146.50 \mathrm{de}$ & $39.33 \mathrm{~b}-\mathrm{e}$ & $42.67 \mathrm{ab}$ & $41.00 \mathrm{ab}$ \\
\hline CIMMYT-HTN 2014/15-4 & $167.33 \mathrm{ef}$ & $123.33 \mathrm{~m}-\mathrm{p}$ & $145.33 \mathrm{fgh}$ & $39.67 \mathrm{bcd}$ & $34.00 \mathrm{~h}-\mathrm{o}$ & $36.83 \mathrm{c}-\mathrm{g}$ \\
\hline Yubileynaya 100 & $165.67 \mathrm{gh}$ & $122.33 \mathrm{o}-\mathrm{s}$ & 144.001 & $34.67 \mathrm{f}-\mathrm{m}$ & 34.33 g-n & $34.50 \mathrm{gh}$ \\
\hline CIMMYT-HTN 2014/15-8 & $166.00 \mathrm{gh}$ & $119.00 \mathrm{t}$ & $142.50 \mathrm{k}$ & $37.00 \mathrm{c}-\mathrm{k}$ & $38.67 \mathrm{~d}-\mathrm{g}$ & $37.83 \mathrm{c}-\mathrm{e}$ \\
\hline CIMMYT-HTN 2013/14-4490 & $165.00 \mathrm{~h} 1$ & $116.67 \mathrm{v}$ & $140.83 \mathrm{~lm}$ & $38.67 \mathrm{~b}-\mathrm{g}$ & $38.00 \mathrm{c}-\mathrm{h}$ & $38.33 \mathrm{a}-\mathrm{d}$ \\
\hline Kate A1 & $167.33 \mathrm{ef}$ & 121.67 qrs & $144.50 \mathrm{~h} 1$ & $32.67 \mathrm{k}-\mathrm{p}$ & $33.00 \mathrm{j}-\mathrm{o}$ & 32.83 hil \\
\hline CIMMYT-HTN 2014/15-5 & $168.33 \mathrm{de}$ & $121.33 \mathrm{n}-\mathrm{r}$ & 144.83 gh1 & $36.00 \mathrm{c}-\mathrm{k}$ & $36.33 \mathrm{c}-\mathrm{k}$ & $36.17 \mathrm{c}-\mathrm{g}$ \\
\hline CIMMYT-HTN 2014/15-7 & $172.33 \mathrm{a}$ & 124.001 & $148.17 \mathrm{ab}$ & $31.00 \mathrm{~m}-\mathrm{q}$ & $28.67 \mathrm{p}-\mathrm{t}$ & $29.83 \mathrm{~lm}$ \\
\hline Basribey & $165.00 \mathrm{~h} 1$ & $118.00 \mathrm{tu}$ & $141.50 \mathrm{kl}$ & $31.00 \mathrm{~m}-\mathrm{q}$ & $30.33 \mathrm{nr}$ & 30.671 \\
\hline Esperia & $168.00 \mathrm{def}$ & $123.00 \mathrm{n}-\mathrm{q}$ & $145.50 \mathrm{e}-\mathrm{h}$ & $30.00 \mathrm{o}-\mathrm{s}$ & $31.671-\mathrm{q}$ & 30.83 1l \\
\hline CIMMYT-HTN 2013/14-4492 & $165.00 \mathrm{~h} 1$ & $118.33 \mathrm{t}$ & $141.67 \mathrm{kl}$ & $38.00 \mathrm{c}-\mathrm{h}$ & $39.00 \mathrm{~b}-\mathrm{f}$ & $38.50 \mathrm{a}-\mathrm{d}$ \\
\hline CIMMYT-HTN 2013/14-4489 & $165.33 \mathrm{~h} 1$ & $117.00 \mathrm{uv}$ & 141.171 & $37.67 \mathrm{c}-1$ & $38.00 \mathrm{c}-\mathrm{h}$ & $37.83 \mathrm{c}-\mathrm{e}$ \\
\hline CIMMYT-HTN 2014/15-1 & $170.00 \mathrm{bc}$ & $124.33 \mathrm{~lm}$ & $147.17 \mathrm{bcd}$ & $34.33 \mathrm{~g}-\mathrm{n}$ & $33.331-0$ & 33.83 gh1 \\
\hline Dropia & $168.00 \mathrm{def}$ & $122.00 \mathrm{prs}$ & $145.00 \mathrm{gh} 1$ & $37.67 \mathrm{c}-1$ & $37.67 \mathrm{c}-1$ & $37.67 \mathrm{c}-\mathrm{f}$ \\
\hline CIMMYT-HTN 2014/15-2 & $167.67 \mathrm{ef}$ & $121.33 \mathrm{n}-\mathrm{r}$ & $144.50 \mathrm{~h} 1$ & $35.33 \mathrm{~d}-1$ & $34.00 \mathrm{~h}-\mathrm{o}$ & $34.67 \mathrm{fgh}$ \\
\hline CIMMYT-HTN 2014/15-3 & $166.67 \mathrm{fg}$ & $122.33 \mathrm{o}-\mathrm{s}$ & $144.50 \mathrm{~h} 1$ & $26.33 \mathrm{st}$ & 34.33 g-n & $30.33 \mathrm{~lm}$ \\
\hline Nota & $169.33 \mathrm{~cd}$ & $123.00 \mathrm{~m}-\mathrm{q}$ & $146.17 \mathrm{def}$ & $32.67 \mathrm{k}-\mathrm{p}$ & $35.33 \mathrm{~d}-1$ & $34.00 \mathrm{gh}$ \\
\hline Mean & $167.86 \mathrm{~b}$ & $121.80 \mathrm{a}$ & & 34.77 & 35.13 & \\
\hline
\end{tabular}


and CIMMYT-HTN 2013/14-4464 genotypes. The CIMMYT bread wheat breeding program focused on developing early-maturing and heat tolerant wheat lines. Early maturity to escape high temperature stress has been suggested that is an excellent crop adaptation approach in regions suffering from terminal and continual high temperature stress [31, 32]. In late sowing, the longest heading time was obtained for CIMMYT-HTN 2014/15-9 genotype with 126.33 days, and followed by Syrena cultivar with 125.0 days. The shortest heading time was determined for CIMMYT-HTN 2013/14-4490 with 116.67 days, and followed by CIMMYT-HTN 2013/14-4489 with 117.00 days. When grain yields of genotypes are examined in terms of heading time, it is seen that genotypes generally have a shorter heading time in late sowing than that of standard sowing, resulting in a decrease in yields. Higher temperatures at post-anthesis stage in wheat increase the rate but reduce the duration of seed filling [13, 22, 33]. When bread wheat genotypes were examined for thousand kernel weights, which are one of the important yield and quality characteristics, it ranged from 25.67 to $43.67 \mathrm{~g}$ for standard sowing and ranged from 24.33 to 41.00 for late sowing. As can be seen from the obtained data, the intervals of change are close to each other due to late planting and early seeding for thousand kernel weight. The results show that the heading time is significantly affected by high temperature, while the thousand kernel weight is relatively low.

Results of the test weight and the grain yield obtained from standard and late sowing for wheat genotypes are given in Table 3.

When the test weight and the grain yield value of examined for the 30 bread wheat genotypes obtained in the experiment, significant variations were obtained according to the sowing time. The test weight ranged from 72.00 to $82.33 \mathrm{~kg} / \mathrm{hL}$ in the standard sowing, and ranged from 77.33 to $82.00 \mathrm{~kg} / \mathrm{hL}$ in the late sowing. The test weight in the late sowing was higher than that of standard sowing for some varieties. CIMMYT-HTN 2013/15-44 genotype gave the highest test weight of $82.33 \mathrm{~kg} / \mathrm{hL}$, and followed by CIMMYT-HTN 2014/15-5 and CIMMYT-HTN 2014/15-4 genotypes in standard sowing. In the late sowing, the highest test weight was obtained for CIMMYT-HTN 2014/15-5 with $82.00 \mathrm{~kg} / \mathrm{hL}$, which was followed by CIMMYT-HTN 2013/14-4490, CIMMYT-HTN 2013/14-4464， CIMMYT-HTN 2014/15-6, Basribey, Syrena and Krasunia genotypes. As can be seen from the results obtained, high temperature-resistant genotypes from CIMMTY, Basribey cultivar known for its high temperature resistance in our country and Syrena and Krasunia cultivars originated from Ukrainian grown in the Thrace region gave the most appropriate mean for test weight (Table 3). The lowest values for test weight were obtained in CIMMYT-HTN 2014/15-6 genotype with $72.00 \mathrm{~kg} / \mathrm{hL}$ for standard sowing, followed by CIMMYT-HTN 2014/15-2, Saraybosna and Golia genotypes. In late sowing, the lowest test values $(77.33 \mathrm{~kg} / \mathrm{hL})$ were obtained in the Gelibolu cultivar, followed by CIMMYT-HTN 2014/15-3 and Flamura 85 with $77.67 \mathrm{~kg} / \mathrm{hL}$. These results show that the effect of high temperature on the test weights of bread wheat genotypes is quite different. It has been reported that grain yields and quality decline at higher than optimal temperatures $[14,34]$.

When the yields of the wheat genotypes used in the study were examined, average yield was between 459.25 and $686.67 \mathrm{~kg} / \mathrm{da}$ in standard sowing, while those in late sowing varied between 388.00 to 614.00 $\mathrm{kg} / \mathrm{da}$. Refs. $[15,16]$ have shown decreasing effects on grain yield of high temperature. The highest grain yields in standard sowing were $686.67 \mathrm{~kg} / \mathrm{da}$ and $685.33 \mathrm{~kg} / \mathrm{da}$ with CIMMYT-HTN 2013/14-4492 and CIMMYT-HTN 2013/14-4489, respectively. These genotypes followed CIMMYT-HTN 2014/15-5 with $676.00 \mathrm{~kg} / \mathrm{da}$ and Nota with $673.00 \mathrm{~kg} / \mathrm{da}$. The highest grain yield $(614.00 \mathrm{~kg} / \mathrm{da})$ in late sowing was obtained from CIMMYT-HTN 2014/15-4 genotype, which was 
Table 3 Mean values and significances of test weight and grain yield for bread wheat genotypes.

\begin{tabular}{|c|c|c|c|c|c|c|}
\hline \multirow[b]{2}{*}{ Genotypes } & \multicolumn{3}{|c|}{ Test weight $(\mathrm{kg} / \mathrm{hL})$} & \multicolumn{3}{|c|}{ Grain yield $(\mathrm{kg} / \mathrm{da})$} \\
\hline & $\begin{array}{l}\text { Standard } \\
\text { sowing }\end{array}$ & $\begin{array}{l}\text { Late } \\
\text { sowing }\end{array}$ & Mean & $\begin{array}{l}\text { Standard } \\
\text { sowing }\end{array}$ & $\begin{array}{l}\text { Late } \\
\text { sowing }\end{array}$ & Mean \\
\hline Golia & $74.67 \mathrm{j}-\mathrm{m}$ & $77.33 \mathrm{e}-\mathrm{j}$ & $76.00 \mathrm{~lm}$ & $478.00 \mathrm{p}-\mathrm{v}$ & $514.00 \mathrm{j}-\mathrm{t}$ & $496.00 \mathrm{gh} 1$ \\
\hline CIMMYT-HTN 2013/14-4464 & $82.33 \mathrm{a}$ & $81.33 \mathrm{a}-\mathrm{d}$ & $81.33 \mathrm{a}$ & 561.67 e-p & $594.67 \mathrm{~b}-\mathrm{j}$ & 578.17 a-f \\
\hline Gelibolu & $77.33 \mathrm{e}-\mathrm{j}$ & $77.33 \mathrm{e}-\mathrm{j}$ & 77.33 e-m & $583.33 \mathrm{~d}-\mathrm{m}$ & $474.33 \mathrm{q}-\mathrm{v}$ & $528.83 \mathrm{fgh}$ \\
\hline Krasunia & $76.67 \mathrm{f}-\mathrm{k}$ & $81.33 \mathrm{a}-\mathrm{d}$ & $79.00 \mathrm{~b}-1$ & 565.00 e-n & $556.33 \mathrm{f}-\mathrm{q}$ & $560.67 \mathrm{c}-\mathrm{f}$ \\
\hline Flamura 85 & $78.33 \mathrm{c}-1$ & $76.67 \mathrm{f}-\mathrm{k}$ & $77.50 \mathrm{e}-\mathrm{m}$ & $609.00 \mathrm{a}-1$ & $494.33 \mathrm{n}-\mathrm{u}$ & $551.67 \mathrm{c}-\mathrm{f}$ \\
\hline CIMMYT-HTN 2014/15-9 & 79.00 a-h & $79.00 \mathrm{a}-\mathrm{h}$ & $79.00 \mathrm{~b}-1$ & 571.67 e-n & $564.00 \mathrm{e}-\mathrm{o}$ & $567.84 \mathrm{~b}-\mathrm{f}$ \\
\hline CIMMYT-HTN 2014/15-10 & $72.00 \mathrm{~m}$ & $79.33 \mathrm{a}-\mathrm{g}$ & $75.67 \mathrm{~m}$ & $459.25 \mathrm{t}-\mathrm{w}$ & 428.50 uvw & $443.85 \mathrm{ij}$ \\
\hline Saraybosna & $74.67 \mathrm{j}-\mathrm{m}$ & $79.33 \mathrm{a}-\mathrm{g}$ & $77.00 \mathrm{~g}-\mathrm{m}$ & $500.33 \mathrm{~m}-\mathrm{u}$ & $471.67 \mathrm{q}-\mathrm{v}$ & $486.00 \mathrm{~h} 1 \mathrm{j}$ \\
\hline Tekirdağ & $77.00 \mathrm{e}-\mathrm{j}$ & $77.67 \mathrm{e}-\mathrm{j}$ & $77.33 \mathrm{e}-\mathrm{m}$ & $487.00 \mathrm{n}-\mathrm{u}$ & $479.00 \mathrm{o}-\mathrm{v}$ & $483.00 \mathrm{~h} 1 \mathrm{j}$ \\
\hline Syrena & $78.00 \mathrm{~d}-\mathrm{j}$ & $81.33 \mathrm{a}-\mathrm{d}$ & $79.67 \mathrm{a}-\mathrm{e}$ & $504.00 \mathrm{k}-\mathrm{u}$ & $555.00 \mathrm{f}-\mathrm{r}$ & $529.50 \mathrm{fgh}$ \\
\hline CIMMYT-HTN2013/14-4488 & $78.67 \mathrm{~b}-\mathrm{h}$ & $80.00 \mathrm{a}-\mathrm{f}$ & $79.33 \mathrm{a}-\mathrm{g}$ & $663.00 \mathrm{a}-\mathrm{d}$ & $505.67 \mathrm{k}-\mathrm{u}$ & $584.34 \mathrm{a}-\mathrm{f}$ \\
\hline Tina & $73.67 \mathrm{klm}$ & $78.67 \mathrm{~b}-\mathrm{h}$ & $76.17 \mathrm{klm}$ & 609.33 a-1 & $471.33 \mathrm{r}-\mathrm{v}$ & 540.17 efg \\
\hline CIMMYT-HTN 2014/15-6 & $72.00 \mathrm{~m}$ & $81.33 \mathrm{a}-\mathrm{d}$ & 76.67 1-m & $546.00 \mathrm{~g}-\mathrm{s}$ & $536.00 \mathrm{~h}-\mathrm{t}$ & $541.00 \mathrm{efg}$ \\
\hline Pehlivan & $79.00 \mathrm{a}-\mathrm{h}$ & 80.33 a-e & 79.67 a-e & $553.67 \mathrm{f}-\mathrm{r}$ & $564.00 \mathrm{e}-\mathrm{o}$ & $558.84 \mathrm{c}-\mathrm{f}$ \\
\hline CIMMYT-HTN 2014/15-4 & $80.00 \mathrm{a}-\mathrm{f}$ & $78.00 \mathrm{~d}-\mathrm{j}$ & $79.00 \mathrm{~b}-1$ & $627.00 \mathrm{a}-\mathrm{g}$ & $614.00 \mathrm{a}-\mathrm{h}$ & $620.50 \mathrm{ab}$ \\
\hline Yubileynaya 100 & $75.67 \mathrm{~h}-1$ & $78.00 \mathrm{~d}-\mathrm{j}$ & $76.33 \mathrm{~h}-\mathrm{m}$ & $639.00 \mathrm{a}-\mathrm{f}$ & 538.00 e-n & 588.50 a-e \\
\hline CIMMYT-HTN 2014/15-8 & $79.00 \mathrm{a}-\mathrm{h}$ & $78.00 \mathrm{~d}-\mathrm{j}$ & $78.50 \mathrm{c}-\mathrm{k}$ & $563.33 \mathrm{e}-\mathrm{o}$ & $388.00 \mathrm{w}$ & $475.67 \mathrm{~h} 1 \mathrm{j}$ \\
\hline CIMMYT-HTN 2013/14-4490 & $79.00 \mathrm{a}-\mathrm{h}$ & $81.67 \mathrm{abc}$ & $80.33 \mathrm{abc}$ & $663.00 \mathrm{a}-\mathrm{d}$ & $505.67 \mathrm{k}-\mathrm{u}$ & $584.34 \mathrm{a}-\mathrm{f}$ \\
\hline Kate A1 & $78.33 \mathrm{c}-1$ & $80.00 \mathrm{a}-\mathrm{f}$ & $79.17 \mathrm{~b}-\mathrm{h}$ & $594.00 \mathrm{~b}-\mathrm{j}$ & $553.33 \mathrm{f}-\mathrm{v}$ & $573.67 \mathrm{~b}-\mathrm{f}$ \\
\hline CIMMYT-HTN 2014/15-5 & $80.00 \mathrm{a}-\mathrm{f}$ & $82.00 \mathrm{ab}$ & $81.00 \mathrm{ab}$ & $673.00 \mathrm{abc}$ & $594.67 \mathrm{~b}-\mathrm{j}$ & $633.84 \mathrm{a}$ \\
\hline CIMMYT-HTN 2014/15-7 & $77.33 \mathrm{e}-\mathrm{j}$ & $78.33 \mathrm{c}-1$ & $77.83 \mathrm{~d}-\mathrm{m}$ & $467.00 \mathrm{~s}-\mathrm{v}$ & $403.33 \mathrm{vw}$ & $435.17 \mathrm{j}$ \\
\hline Basribey & $77.67 \mathrm{e}-\mathrm{j}$ & $81.33 \mathrm{a}-\mathrm{d}$ & $79.50 \mathrm{a}-\mathrm{f}$ & 646.00 a-e & $599.00 \mathrm{~b}-\mathrm{j}$ & $622.50 \mathrm{ab}$ \\
\hline Esperia & $75.001-\mathrm{m}$ & $79.33 \mathrm{a}-\mathrm{g}$ & $77.17 \mathrm{f}-\mathrm{m}$ & $529.00 \mathrm{~h}-\mathrm{t}$ & 566.00 e-n & $547.50 \mathrm{~d}-\mathrm{g}$ \\
\hline CIMMYT-HTN 2013/14-4492 & $77.33 \mathrm{e}-\mathrm{j}$ & $79.33 \mathrm{a}-\mathrm{g}$ & $78.33 \mathrm{c}-1$ & $686.67 \mathrm{a}$ & $526.331-\mathrm{t}$ & $606.50 \mathrm{abc}$ \\
\hline CIMMYT-HTN 2013/14-4489 & $76.67 \mathrm{f}-\mathrm{k}$ & $78.67 \mathrm{~b}-\mathrm{h}$ & $77.67 \mathrm{~d}-\mathrm{m}$ & $685.33 \mathrm{a}$ & $519.33 \mathrm{j}-\mathrm{t}$ & $602.33 \mathrm{a}-\mathrm{d}$ \\
\hline CIMMYT-HTN 2014/15-1 & $79.33 \mathrm{a}-\mathrm{g}$ & $78.33 \mathrm{c}-1$ & $78.83 \mathrm{~b}-1$ & $637.00 \mathrm{a}-\mathrm{f}$ & $606.00 \mathrm{a}-1$ & $621.50 \mathrm{ab}$ \\
\hline Dropia & 78.67 b-h & $81.33 \mathrm{a}-\mathrm{d}$ & 80.00 a-d & $465.33 \mathrm{~s}-\mathrm{v}$ & $502.331-u$ & $483.83 \mathrm{~h} 1 \mathrm{j}$ \\
\hline CIMMYT-HTN 2014/15-2 & $73.33 \mathrm{~lm}$ & $78.67 \mathrm{~b}-\mathrm{h}$ & $76.00 \mathrm{~lm}$ & $593.33 \mathrm{~b}-\mathrm{j}$ & $586.67 \mathrm{~d}-\mathrm{k}$ & 589.84 a-e \\
\hline CIMMYT-HTN 2014/15-3 & 78.67 b-h & $77.67 \mathrm{e}-\mathrm{j}$ & $78.17 \mathrm{c}-1$ & $515.33 \mathrm{j}-\mathrm{t}$ & $589.33 \mathrm{c}-\mathrm{k}$ & $552.33 \mathrm{c}-\mathrm{f}$ \\
\hline Nota & $76.33 \mathrm{~g}-1$ & $80.00 \mathrm{a}-\mathrm{f}$ & $78.17 \mathrm{c}-1$ & $676.00 \mathrm{ab}$ & 562.33 e-p & $619.17 \mathrm{ab}$ \\
\hline Mean & $77.19 \mathrm{~b}$ & $79.39 \mathrm{a}$ & & 576.49 & 531.63 & \\
\hline
\end{tabular}

not included in the highest yield genotype order in standard seeding. This genotype was followed by CIMMYT-HTN 2014/15-1 with $606.00 \mathrm{~kg} / \mathrm{da}$, CIMMYT-HTN 2014/15-5 and CIMMYT-HTN 2013/14-4464.

When grain yield means obtained from sowing times are evaluated, it is shown that genotypes are affected differently from high temperature stress and it is seen that the yields of temperature-resistant genotypes are high in late sowing. Refs. [7-11] have suggested that yield reduction in wheat due to high temperature stress is associated with a decrease in the spike number and weight.

The lowest mean in terms of grain yield was obtained from CIMMYT-HTN 2014/15-10 genotype with $459.25 \mathrm{~kg} / \mathrm{da}$ for standard sowing, followed by Dropia cultivar. In late sowing, CIMMYT-HTN 2014/15-8 genotype gave the lowest yield (388.00 $\mathrm{kg} / \mathrm{da}$ ), followed by CIMMYT-HTN 2014/15-7 genotype with $403.33 \mathrm{~kg} / \mathrm{da}$ and CIMMYT-HTN 2014/15-10 genotype with $428.50 \mathrm{~kg} / \mathrm{da}$.

\section{Conclusions}

The results indicate that grain yields of genotypes 
are significantly affected by high temperature in late sowing. When the bread wheat genotypes are evaluated in terms of tolerance to high temperature, it was shown that Dropia and Nota varieties and CIMMYT-HTN 2014/15-2, CIMMYT-HTN 2014/15-6, CIMMYT-HTN 2014/15-10 lines were better tolerance to high temperature. Besides, these genotypes are not included in the first group due to grain yield for high temperature resistance breeding studies can be recommended as a genitor.

\section{Acknowledgments}

This work was supported by the Office of Scientific Research Projects of Namık Kemal University (Project No. NKUBAP.00.24.AR.14.15).

\section{References}

[1] Wang, W., Vinocur, B., Shoseyov, O., and Altman, A. 2001. "Biotechnology of Plant Osmotic Stress Tolerance: Physiological and Molecular Considerations." Acta Horticulture. 560: 285-92.

[2] Ishag, H. M., and Mohamed, A. B. 1996. "Phasic Development of Spring Wheat and Stability of Yield and Its Components in Hot Environments." Field Crops Res. 46: 169-76.

[3] Reynolds, M. P., Singh, R. P., Ibrahim, A., Ageeb, O. A. A., Larque, S. A., and Quick, J. S. 1998. "Evaluating Physiological Traits to Complement Empirical Selection for Wheat in Warm Environments." Euphytica. 100: 84-95.

[4] Setimela, P. S., Andrews, D., Partridge, J., and Eskridge, K. M. 2005. "Screening Sorghum Seedlings for Heat Tolerance Using a Laboratory Method." Eur. J. Agron. 23: 103-7.

[5] Batts, G. R., Ellis, R. E., Morison, J. I., and Hadley, P. 1998. "Yield and Partitioning in Crops of Contrasting Cultivars of Winter Wheat in Response to $\mathrm{CO}_{2}$ and Temperature in Field Studies Using Temperature Gradient Tunnels.” J. Agric. Sci. 130: 17-27.

[6] Akkaya, A. 1994. "Buğday Yetiştiriciliği." Kahramanmaraş Sütçü Imam Üniv., Ziraat Fakültesi Genel Yayın No:1, Ders Kitaplarl Yayın No:1. Kahramanmaraş.

[7] Tashiro, T., and Wardlaw, I. F. 1990. "The Effect of High Temperature at Different Stages of Ripening on Grain Set, Grain Weight, and Grain Dimensions in the Semi-Dwarf Wheat 'Banks'." Ann. Bot. 65: 51-61.

[8] Shpiler, L., and Blum, A. 1991. "Heat Tolerance for
Yield and Its Components in Different Wheat Cultivars." Euphytica. 51: 257-63.

[9] Wardlaw, I. F., and Wrigley, C. W. 1994. "Heat Tolerance in Temparature Cereals. An Overview." Austr. J. Plant Physiol. 21: 695-703.

[10] Plaut, Z., Butow, B. J., Blumenthal, C. S., and Wrigley, C. W. 2004. "Transport 1085 of Dry Matter into Developing Wheat Kernels and Its Contribution to Grain Yield under Post-anthesis Water Deficit and Elevated Temperature.” Field Crops Res. 86: 185-98.

[11] Hays, K., Maynard, I., Thomas, O., and Bawden, M. 2007. "Sources and Types of Confidence Identified by World Class Sport Performers." J. of Applied Sport Psychology 19: 434-56.

[12] Mohammadi, M. 2012. "Effects of Kernel Weight and Source-Limitation on Wheat Grain Yield under Heat Stress.” Afric. J. Biotech. 11 (12): 2931-7.

[13] Kosina, P., Reynolds, M., Dixon, J., and Joshi, A. 2007. "Stakeholder Perception of Wheat Production Constraints, Capacity Building Needs, and Research Partnerships in Developing Countries." Euphytica 157: 475-83.

[14] Maestri, E., Natalya, K., Perrotta, C., Gulli, M., Nguyen, H., and Marmiroli, N. 2002. "Molecular Genetics of Heat Tolerance and Heat Shock Proteins in Cereals." Plant Mol. Biol. 48: 667-81.

[15] Wardlaw, I. F., Blumenthal, C., Larroque, O., and Wrigley, C. W. 2002. "Contrasting Effects of Chronic Heat Stress and Heat Shock on Grain Weight and Flour Quality in Wheat." Funct. Plant Biol. 29: 25-34.

[16] Bluementhal, C., Bekes, F., Gras, P. W., Barlow, E. W. R., and Wrigley, C. W. 1995. "Influence of Wheat Genotypes Tolerant to the Effects of Heat Stress on Grain Quality." Cereal Chem. 72: 539-44.

[17] Dias, A. S., and Lidon, F. C. 2009. "Evaluation of Grain Filling Rate and Duration in Bread and Durum Wheat, under Heat Stress after Anthesis." J. of Agr. and Crop Sci. 195: 137-47.

[18] Rahman, M. A., Chikushi, J., Yoshida, S., and Karim, A. J. M. S. 2009. "Growth and Yield Components of Wheat Genotypes Exposed to High Temperature Stress under Control Environment." Bangladesh J. of Agric. Res. 34: 361-72.

[19] Shefazadeh, M. K., Mohammadi, M., Karimizadeh, R., and Mohammadinia, G. 2012. "Tolerance Study on Bread Heat Genotypes under Heat Stress.” Annal. Biol. Res. 3 (10): 4786-9.

[20] Balla, K., Zegi, M. R., Li, Z., Békés, F., Ze, S. B., and Veisz, O. 2011. "Quality of Winter Wheat in Relation to Heat and Drought Shock after Anthesis." Czech J. of Food Sci. 29: 117-28.

[21] Chauhan, H., Khurana, N., Nijhavan, A., Khurana, J. P., 
and Khurana, P. 2012. "The Wheat Chloroplastic Small Heat Shock Protein (HSPs26) Is Involved in Seed Maturation and Germination and Imparts Tolerance to Heat Stress." Plant, Cell and Environment 35: 1912-31.

[22] Cossani, C. M., and Reynolds, M. P. 2012. "Physiological Traits for Improving Heat Tolerance in Wheat." Plant Physiol. 160: 1710-8.

[23] Mohammadi, M., Karimzadeh, R., and Abdipour, M. 2011. "Evaluation of Drought Tolerance in Bread Wheat Genotypes under Dryland and Supplemental Irrigation Conditions.” Aust. J. Crop Sci. 5: 487-93.

[24] Sareen, S., Tyagi, B. S., Tiwari, V., and Sharma, I. 2012. "Response Estimation of Wheat Synthetic Lines to Terminal Heat Stress Using Stress Indices.” J. Agri. Sci. 4 (10): 97-104.

[25] Sadat, S., Saeid, K. A., and Bihamta, M. R. 2013. "Marker Assisted Selection for Heat Tolerance in Bread Wheat.” World Applied Sci. J. 21 (8): 1181-9.

[26] Steel, R. G. D., and Torrie, J. H. 1960. Principles and Procedures of Statistics with Special Reference to the Biological Approach. New Yorka: McGraw-Hill.

[27] Reynolds, M. P., Bonnett, D., Chapman, S. C., Furbank, R. T., Manès, Y., Mather, D. E., and Parry, M. A. J. 2011. "Raising Yield Potential of Wheat. I. Overview of a Consortium Approach and Breeding Strategies." J. of Experimental Botany 62: 439-52.

[28] Dillen, S. Y., Marron, N., Koch, B., and Ceulemans, R. 2008. "Genetic Variation of Stomatal Traits and Carbon Isotope Discrimination in Two Hybrid Poplar Families (Populus deltoides 'S9-2' x P. nigra 'Ghoy' and P. deltoides 'S9-2' x P. trichocarpa 'V24').” Ann. Bot. 102: 399-407.
[29] Wang, S. G., Li, Z. Q., Jia, S. S., Sun, D. Z., Shi, Y. G., Fan, H., Liang, Z. H., and Jing, R. L. 2013. "Relationships of Wheat Leaf Stomatal Traits with Wheat Yield and Drought-Resistance.” Ying Yong Sheng Tai Xue Bao 24 (6): 1609-14.

[30] Kapadiya, K. B., Singh, C., Bhalara, R. L., Kandoliya, U. K., and Dabhi, K. H. 2017. "Effect of Higher Temperature on Leaf Anatomy of Heat Tolerance and Heat Susceptible Wheat Genotypes (Triticum aestivum L.) by Scanning Electron Microscopy." Journal of Pharmacognosy and Phytochemistry 6 (5): 2270-7.

[31] Joshi, A. K., Mishra, B., Chatrath, R., Ferrara, G. O., and Singh, R. P. 2007. "Wheat Improvement in India: Present Status: Emerging Challenges and Future Prospects." Euphytica 157: 431-46.

[32] Mondal, S., Singh, R. P., Crossa, J., Huerta-Espino, J., Sharma, I., Chatrath, R., Singh, G. P., Sohu, V. S., Mavi, G. S., Sukuru, V. S. P., Kalappanavar, I. K., Mishra, V. K., Hussain, M., Gautam, N. R., Uddin, J., Barma, N. C. D., Hakim, A., and Joshi, A. K. 2013. "Earliness in Wheat: A Key to Adaptation under Terminal and Continual High Temperature Stress in South Asia." Field Crops Res. 151: 19-26.

[33] Kobata, T., Koç, M., Barutçular, C., Takuta, M., Hiroshi, N., Fmihiko, A., and Ünlü, M. 2012. "Assimilate Supply as a Yield Determination Factor in Spring Wheat under High Temperature Conditions in the Mediterranean zone of South-East Turkey." Plant Prod. Sci. 15: 216-27.

[34] Wardlaw, I. F. 2002. "Interaction between Drought and Chronic High Temperature during Kernel Filling in Wheat in a Controlled Environment." Ann. Botany. 90: 469-76. 